\title{
EFFECT OF AFRICAN LEAVES EXTRACT (Vernonia amygdalina DEL.) ON WOUND HEALING VELOCITY AFTER TOOTH EXTRACTION IN Rattus norvegicus
}

\author{
Andre Kusuma Ruslim ${ }^{*}$, Silvia Anitasari ${ }^{2,3}$, Sjarif Ismail ${ }^{4,5}$, Eka Marwansyah Oli’ ${ }^{6}$, Sinar Yani ${ }^{3,7}$ \\ ${ }^{1}$ Dentistry Program, Faculty of Medicine Mulawarman University \\ ${ }^{2}$ Department of Dental Material, Dentistry Program, Faculty of Medicine Mulawarman University \\ ${ }^{3}$ Departement of Microbiology, Faculty of Medicine Mulawarman University \\ ${ }^{4}$ Departement of Pharmacology, Faculty of Medicine Mulawarman University \\ ${ }^{5}$ Research Center on Drugs and Public Health Mulawarman University \\ ${ }^{6}$ Departement Oral and Maxillofacial Surgery, Faculty of Medicine Mulawarman University \\ ${ }^{7}$ Departement of Oral Biology, Dentistry Program, Faculty of Medicine Mulawarman University \\ *Corresponding author email : andrekusumaaa@gmail.com
}

\begin{abstract}
Povidone iodine is an antiseptic that is often used for wounds after tooth extraction, but is often debated because it can cause damage to cells and tissues. African leaf (Vernonia amygdalina Del.) from the family Asteraceae has saponins as anti-microbial, anti-inflammatory and antioxidant flavonoids as that all may be able to accelerate wound healing. To investigate the activity of extracts of Vernonia amygdalina folia (VAF) to accelerate the process of wound healing after tooth extraction in rats. VAF extracted by maceration using methanol. Wistar male rats as much as 6 groups ( $n=5$ mice each group) performed tooth extractions, and then observed the reduction of gingival socket closure for 21 days after being given povidone iodine, distilled water and methanol extract group VAF by 4 concentration. The closure of the wound after tooth extraction in the group of povidone iodine rats occurred on the 8th day, the group aquadest cover the wound occurred on the 12th day, the extract group 1, 3, 5, 7\% sequentially occur wound closure on day 6th, 5th, 4th and 4th. $V A F$ methanol extract of the leaves can accelerate wound healing after tooth extraction of mice.
\end{abstract}

Keywords: leaves, Vernonia amygdalina, extract, extraction of tooth, wound healing.

Submitted on:8 November 2017 Accepted on: 8 December 2017

DOI: https://doi.org/10.25026/jsk.v1i8.79

\section{PENDAHULUAN}

Penyembuhan luka setelah pencabutan gigi merupakan proses kompleks dan dinamis dari perbaikan struktur sel dan jaringan. Proses penyembuhan luka terdiri dari beberapa fase yaitu fase hemostasis, fase inflamasi, fase proliferasi dan fase remodelling $[1,2]$. Salah satu faktor yang menghambat penyembuhan luka baik pada jaringan lunak maupun bagian tubuh lain adalah infeksi pada luka. Salah satu cara untuk mengatasi infeksi dengan pemberian antiseptik, povidone iodine merupakan salah satu antiseptik yang sering digunakan setelah pencabutan gigi, tetapi masih diperdebatkan oleh kalangan medis karena dapat menyebabkan kerusakan sel dan jaringan [3]. Masih diperlukan penelitian invensi bahan-bahan lain yang dapat digunakan untuk mempercepat penyembuhan luka tanpa menyebabkan kerusakan sel dan jaringan, terutama berbasis herbal yang ada di Indonesia dan terjangkau oleh masyarakat [4].

Kalimantan Timur kaya akan tumbuhan obat, Vernonia amygdalina Del. folia (VAF) dari famili Asteraceae cukup potensial untuk diteliti lebih lanjut sebagai bahan ekstrak yang dapat mempercepat penyembuhan luka. VAF telah diteliti memiliki kandungan 
antioksidan yang dapat mempercepat menyembuhan luka dan berefek antiinflamasi [5] serta anti bakteri [6]. Masih belum diketahui efek VAF pada proses penyembuhan luka, terutama setelah ekstraksi gigi karena di dalam rongga mulut banyak terdapat bakteri. Tujuan dari penelitian ini untuk mengetahui aktivitas ekstrak VAF terhadap proses percepatan penyembuhan luka dengan menggunakan model hewan uji tikus yang dilakukan tindakan ekstraksi gigi. Adapun manfaat dari penelitian ini diharapkan kemudian hari dapat dimanfaatkan sebagai salep untuk mempercepat penyembuhan luka setelah pencabutan gigi.

\section{METODE PENELITIAN}

\section{Rancangan Penelitian dan Persetujuan Etik}

Penelitian ini dengan disain post only control design with randomized. Tikus putih jantan galur Wistar (Rattus novergicus) umur 2-4 bulan dari Laboratorium Farmakologi Fakultas Kedokteran Universitas Mulawarman dengan kondisi lingkungan sesuai dengan standar. Pakan hewan sesuai dengan pakan standar dengan akses bebas dan minum dari air yang difiltrasi dengan akses bebas. Protokol penelitian sebelum dimulai sudah disetujui oleh Komisi Etik Penelitian Fakultas Kedokteran Universitas Mulawarman. Tikus putih jantan galur wistar dipilih karena tidak dipengaruhi oleh siklus menstruasi dan kehamilan sehingga memberikan hasil penelitian yang lebih stabil dibandingkan tikus betina. Tikus jantan juga mempunyai kecepatan metabolisme obat lebih cepat dan kondisi biologis tubuh yang lebih stabil dibanding tikus betina [7].

\section{Pengambilan Tumbuhan dan Ektraksi}

VAF diambil dari Kabupaten

Kutai Kartanegara, Kalimantan Timur pada bulan Mei 2017. Identifikasi jenis dibantu oleh ahli taksonomi dari Fakultas Kehutanan. Herbarium disimpan di Laboratorium Farmakologi Universitas Mulawarman dengan kode voucher No. VA01/V/2017 yang dapat dilakukan identifikasi ulang jika diperlukan. VAF disortasi, dicuci dengan air bersih mengalir lalu dikeringkan dalam oven suhu $60^{\circ} \mathrm{C}$, setelah kering digiling. Simplisia diekstraksi secara maserasi dengan metanol pada suhu kamar selama 3 hari dan diulang sebanyak 2 kali. Ekstrak dipekatkan dengan vakum rotavapor suhu $50^{\circ} \mathrm{C}$, selanjutnya dimasukkan kedalam desikator yang berisi silika gel biru dalam oven $60^{\circ} \mathrm{C}$ hingga didapatkan ekstrak kering. ekstrak tersebut kemudian disimpan dalam lemari pendingin $4^{\circ} \mathrm{C}$ sebelum diujikan.

\section{Uji Aktivitas Penyembuhan Luka pada Tikus}

Tikus Wistar sebanyak 30 ekor diadaptasi dalam kandang selama 3 hari. Tikus dibagi dalam 4 kelompok perlakuan konsentrasi ekstrak VAF $1 \%$ (EVAF1), EVAF 3\% (EVAF3), VAF 5\% (EVAF5), dan VAF 7\% (EVAF7), kelompok Kontrol Positif: povidone iodine (KP), kelompok Kontrol Negatif: air suling (KN). Masing-masing kelompok terdiri dari 5 ekor tikus.Sebelum pencabutan gigi, terlebih dahulu diinjeksikan ketamin $10 \mathrm{mg} / \mathrm{kg}$ BB secara intra muskular pada paha kanan untuk memberikan efek sedasi. Satu persatu tikus dilakukan pencabutan pada salah satu Incisivus Maxilla. Penghitungan diameter soket dilakukan sampai dengan 21 hari dan terlihat tandatanda klinis pada soket seperti soket tertutup oleh selapis tipis mukosa, terjadinya pengerutan maksimal pada 
bekas luka dan tidak adanya bintik merah pada sekitar luka. Pada kelompok EVAF1, EVAF3, EVAF5 EVAF7 dioleskan ekstrak, pada kelompok KP dioleskan povidone iodine, dan pada kelompok $\mathrm{KN}$ dioleskan air suling. Ekstrak dioleskan dengan menggunakan kassa platelet sehari 2 kali pada pagi (jam 08.00) dan sore (jam 15.00).

\section{Analisa Data}

Reduksi soket rata-rata yang dihitung adalah diameter soket terbesar ditambah dengan diameter soket terkecil dan dibagi dengan jumlah diameter yang dihitung pada satu soket. Reduksi soket rata-rata dikonversi kedalam presentase reduksi diameter soket untuk mempermudah penghitungan dengan rumusan soket keseluruan atau 1 dikurangi dengan diameter soket hari sebelumnya (d0) di kurangi dengan diameter soket hari penghitungan (dt) dibagi dengan diameter soket hari sebelumnya (d0) kemudian dikalikan $100 \%$. Selanjutnya dihitung area under curve (AUC) untuk mengetahui efektivitas ekstrak yang diujikan pada setiap kelompok. Semua data disajikan dalam mean \pm SD. Uji statistik menggunakan program SPSS v. 22 degan uji ANOVA, berbeda bermakna jika $p<0,05$.

\section{HASIL DAN PEMBAHASAN}

Hasil penelitian pada kelompok KP, KN, EVAF1 EVAF3, EVAF5, dan EVAF7 didapatkan presentase reduksi diameter soket bervariasi. Pada Gambar 1 tampak penyembuhan tercepat terjadi pada kelompok EVAF7 dan EVAF5, keduanya soket menutup pada hari ke-4 dengan presentase penutupan soket yang masih yang belum tertutup pada hari ke 3 sebesar $(0,45 \pm 0,05)$ dan $(0,58 \pm 0,05)$. Kelompok EVAF3 menutup pada hari ke5 dengan presentase penutupan soket yang masih yang belum tertutup pada hari ke-4 sebesar $(0,40 \pm 0,01)$. Kelompok EVAF1 menutup pada hari ke6 dengan persentase penutupan soket yang masih yang belum tertutup pada hari ke-5 sebesar $(0,36 \pm 0,05)$. Kelompok KP menutup pada hari ke-8 dengan presentase penutupan soket yang masih yang belum tertutup pada hari ke-7 sebesar $(0,32 \pm 0,06)$. Kelompok $\mathrm{KN}$ menutup pada hari ke-12 dengan presentase penutupan soket yang masih yang belum tertutup pada hari ke-11 sebesar $(0,33 \pm 0,07)$. Nilai AUC pada grafik dihitung dan didapatkan hasil seperti pada Tabel 1.

Persentase reduksi ukuran soket setelah pencabutan gigi tikus dari hari ke hari semakin tampak di setiap kelompok Kontrol maupun kelompok perlakuan, akan tetapi jumlah rata-rata persentase reduksi terbesar ditunjukkan pada kelompok EVAF5 dan EVAF7. Ini mungkin disebabkan oleh keberadaan aktivitas antioksidan, antiinflamasi dan antibakteri yang terdapat ekstrak EVAF. Salah satu antioksidan yang terkandung dalam EVAF adalah metabolit sekunder kelompok dari flavonoid. Flavonoid merupakan antioksidan yang lebih kuat beberapa kali dibandingkan dengan vitamin C [6]. Potensi dari kandungan antioksidan dalam flovanoid tanaman ini mungkin sebagai salah satu penyebab dari peningkatan penyembuhan luka.

Catatan: $n=5$ ekor, nilai disajikan dalam mean \pm SD. EVAF1 = ekstrak Vernonia amygdalina konsentrasi $1 \%$, EVAF3 = ekstrak Vernonia amygdalina konsentrasi 3\%, EVAF5 = ekstrak konsentrasi 5\%, EVAF7 = ekstrak Vernonia amygdalina konsentrasi 7\%, $\mathrm{KP}=$ Kontrol Positif (povidone iodine) dan $\mathrm{KN}=$ Kontrol Negatif (air suling).

Infeksi bakteri dapat memperlambat penyembuhan luka karena bakteri dan endotoksin yang dimilikinya 
Effect of African Leaves Extract (Vernonia amygdalina Del.) on Wound Healing Velocity After Tooth Extraction in Rattus norvegicus

dapat meningkatkan sitokin yang proinflamasi seperti interleukin-1 dan tumor necrosis factor- $\alpha$, keduanya menyebabkan pemanjangan fase inflamasi. Penelitian sebelumnya pada VAF didapatkan tanin. Tanin diketahui dapat membentuk lapisan protektif pada luka sehingga luka dapat terlindung dari mikroorganisme yang berpotensi menyebabkan infeksi. Potensi dari kandungan tanin juga yang mungkin merupakan salah satu penyebab dari peningkatan kecepatan penyembuhan luka karena dapat berperan sebagai antibakteri. Secara histologis kandungan tanin pada tanaman telah terbukti dapat membantu proses penyembuhan luka dengan meningkatkan proliferasi sel dan mencegah proses oksidasi $[12,13]$.

Tabel 1. Nilai AUC grafik reduksi persentase rata-rata penutupan luka pada kelompok Kontrol dan EVAF berbagai konsentrasi.

\begin{tabular}{cl}
\hline Kelompok & Nilai AUC \\
\hline KP & $4,21 \pm 0,20^{* \# \#}$ \\
KN & $7,46 \pm 0,07^{* \#}$ \\
EVAF1 & $2,20 \pm 0,17^{* * *}$ \\
EVAF3 & $2,18 \pm 0,17^{* *}$ \\
EVAF5 & $1,36 \pm 0,14^{*}$ \\
EVAF7 & $1,48 \pm 0,08^{*}$ \\
\hline
\end{tabular}

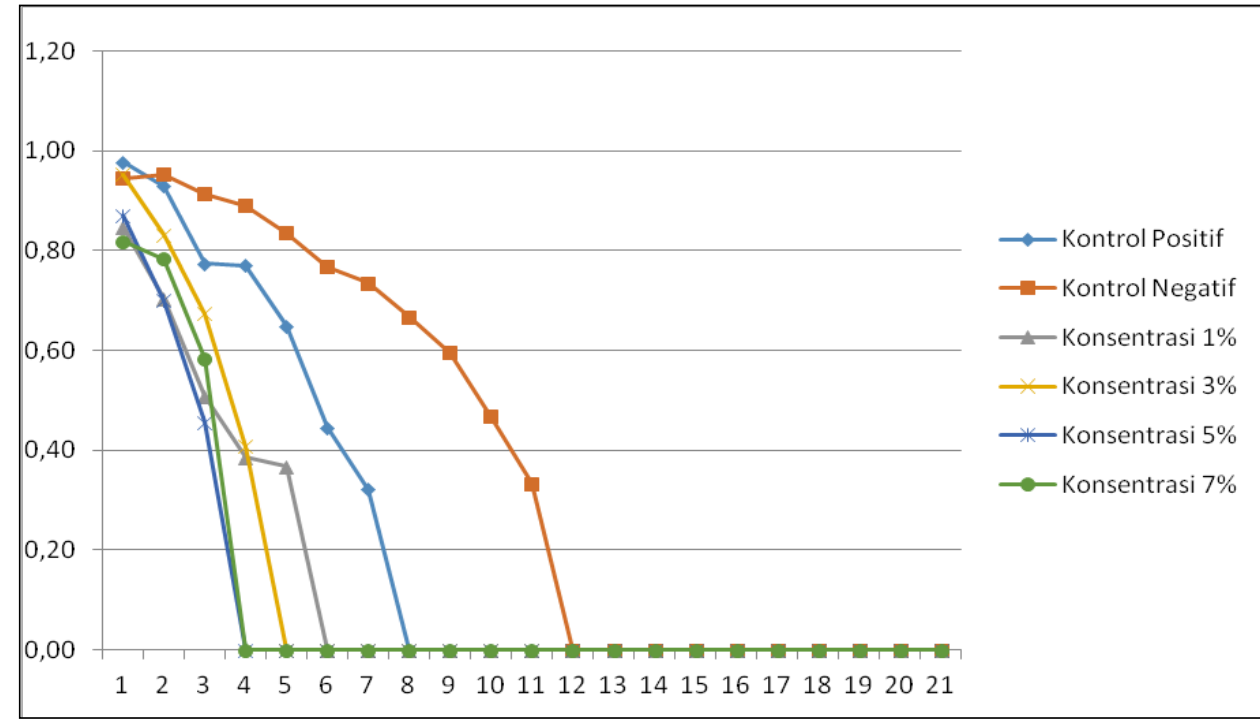

Gambar 1. Grafik reduksi persentase rata-rata penutupan luka setelah pencabutan gigi dengan pemberian Kontrol dan EVAF berbagai konentrasi

Saat gigi dikeluarkan dari soketnya akan terjadi kerusakan pada pembuluh darah perifer sehingga menyebakan darah akan mengisi daerah pencabutan $[14,15]$. Saponin merupakan salah satu metabolit sekunder terdapat pada VAF yang diduga dapat mempercepat dari proses penyembuhan luka dengan cara mempercepat persipitasi dan koagulasi sel darah merah serta dapat membantuk pembentukan pembuluh darah baru, Studi terbaru menunjukkan 
bahwa efektivitas banyak pengobatan herbal dipengaruhi karena saponin sebagai bahan aktifnya. Selain itu penelitian mendapatkan kontribusi saponin pada makanan yang memberikan keuntungan pada kesehatan $[12,17,16]$. Pada saat gigi dikeluarkan dari soketnya akan terjadi kerusakan pada pembuluh darah perifer sehingga menyebakan darah akan mengisi daerah pencabutan [8]. Saponin merupakan salah satu metabolit sekunder terdapat pada VAF yang diduga dapat mempercepat dari proses penyembuhan luka dengan cara mempercepat persipitasi dan koagulasi sel darah merah serta dapat membantuk pembentukan pembuluh darah baru [4].

Keterangan: $\mathrm{n}=5$, nilai disajikan dalam mean \pm SD EVAF1 = ekstrak Vernonia amygdalina konsentrasi 1\%, EVAF3 = ekstrak Vernonia amygdalina konsentrasi 3\%, EVAF5 = ekstrak konsentrasi 5\%, EVAF7 = ekstrak Vernonia amygdalina konsentrasi 7\%, KP $=$ Kontrol Positif (povidone iodine) dan $\mathrm{KN}=$ Kontrol Negatif (air suling). Uji Anova berbeda bermakna jika $\mathrm{p}<0.05$; *berbeda bermakna dengan $\mathrm{KP}, \mathrm{KN}$, EVAF1, EVAF3; **berbeda bermakna dengan KP, KN, EVAF5, EVAF7; *** berbeda bermakna dengan $\mathrm{KP}, \mathrm{KN}$; *\# dan *\#\# berbeda bermakna dengan semua kelompok.

Dilihat dari lama penutupan luka, kelompok EVAF1 dan EVAF3 mempunyai hasil berbeda bermakna jika dibandingkan dengan kelompok KP dan KN. Kelompok EVAF1 dan EVAF3 dalam konsentrasi kecil (1\% dan 3\%) dapat meningkatkan kecepatan penyembuhan luka walaupun tidak terlihat berbeda bermakna dengan kelompok EVAF5 dan EVAF7. Pada hasil penghitungan nilai AUC tampak kelompok EVAF5 lebih efektif dibandingkan dengan EVAF7. Efektifitas konsentrasi ekstrak ini dapat dilihat dari nilai AUC yang dihitung mulai dari hari ke-1 sampai dengan hari ke-4 menunjukkan bahwa kelompok EVAF5 memiliki AUC yang lebih kecil dibandingkan dengan EVAF7, ditambah lagi penampakan secara makrospkopis menunjukkan bahwa mukosa pada kelompok EVAF7 lebih terlihat kemerahan yang bisa saja menandakan terjadinya iritasi pada daerah mukosa setelah diberikan perlakuan. Diperlukan penelitian lanjutan untuk dilakukan uji hipersenstivitas untuk diketahui ada atau tidaknya efek iritasi. Hasil penelitian ini juga mempertegas penelitian pada luka bakar yang diberi ekstrak gel VAF dapat mempercepat proses penyembuhan luka [7].

Penelitian ekstrak tumbuhan herbal dalam efektifitas mempercepat proses penyembuhan luka tidak terlepas dari kandungan zat aktif flavonoid sebagai antioksidan, tanin sebagai antibakteri dan antiinflamasi, serta saponin dalam mempercepat persipitasi sel. Kesemuanya ini secara sendirisendiri maupun secara orkestra dapat secara efektif mempercepat proses penyembuhan luka seperti ekstrak daun kecombrang (Etlingera elatior) yang efektif dalam mempercepat proses penyembuhan luka pada konsentrasi $9 \%$ dengan zat aktif yang terdapat didalam ekstrak daun tersebut adalah flavonoid, saponin dan polifenol. Ekstrak daun binahong (Anredera cordifolia) mempercepat penyembuhan luka pada kosentrasi $10-15 \%$ dengan zat aktif yang terdapat didalam ekstrak daun tersebut adalah saponin, flavonoid, polifenol dan alkaloid. Ekstrak daun alpukat (Parsea americana) efektif mempercepat penyembuhan luka pada konsentrasi 50\% dengan zat aktif yang terdapat dalam ekstrak daun tersebut adalah saponin, tanin, glikosida, dan flavonoid. Esktrak daun pandan wangi (Pandanus 
amaryllifolius) pada konsentrasi $50 \%$ juga dapat mempercepat penyembuhan luka mengandung metabolit sekunder flavonoid, saponin, dan tanin $[1,18,19,20]$.

\section{KESIMPULAN}

Hasil penelitian ini
memperlihatkan ekstrak metanol $V$.
amygdalina mempunyai efek
mempercepat penyembuhan luka dilihat
dari hari menutupnya luka setelah
pencabutan gigi Rattus novergicus dan
konsentrasi yang efektif adalah 5\%.

\section{UCAPAN TERIMAKASIH}

Peneliti mengucapkan terimakasih kepada Kepala Departemen Farmakologi Fakultas Kedokteran Universitas Mulawarman, Kepala Departemen Dental Material dan Kepala Departemen Oral Biologi Program Studi Pendidikan Dokter Gigi yang telah membantu peneliti dalam menyelesaikan penelitian ini.

\section{DAFTAR PUSTAKA}

[1] Nofikasari I, Rufaida A, Aqmarina CD, Failasofia Fauzia AR, \& Handajani J. 2016. Efek Aplikasi Topikal Gel Ekstrak Pandan Wangi terhadap Penyembuhan Luka Ginggiva. Majalah Kedokteran Gigi Indonesia, 2(2):53-59.

[2] Syam IA, Hatta R, \& Ruslin M. 2015. Potensi dari Ceker Ayam Kampung (Gallus domesticus) untuk Mempercepat Penyembuhan Soket Pasca Ekstraksi Gigi. Makasar Dental Journal, 4(2):50-55.

[3] Miladiyah I, \& Prabowo BR. 2012. Ethanolic Extract of Anredera cordofolia (Ten.) Steenis Leaves Improved Wound Healing in Guinea Pigs. Universa Medicina, 31:4-11.

[4] Departemen Kesehatan Republik Indonesia. 2008. Farmakope Herbal Indonesia, ed.1, Jakarta: Departemen Kesehatan RI.

[5] Adesanoya O, Ifezue A, \& Farombi E. 2014. Influence od Chlorampenicol and Amoxicillin on Rat Liver Mircrosomal Enzymes and Lipid Perioxodation. African
Journal Of Biomedical Resaerch, 17:135142.

[6] Oboh FO, \& Masodje HI. 2009. Nutritional and Anti Microbial Properties of Vernonia amygdalina Leaves. International Jounal of Biomedical and Health Sciens, 5(2):51-56.

[7] Ngatidjan. 2006. Metode Laboratorium dalam Toksikologi, Metode Uji Toksisitas.

[8] Dorland, \& Newman, W. 2002. Kamus Kedokteran Dorland, Edisi 29. Jakarta: EGC.

[9] Rosanto YB, Handajani J, \& Susilowati H. 2012. Efek Pemberian Gel Getah Batang Tanaman Pisang Secara Topikal Terhadap Kepadatan Serabut Kolagen pada Proses Penyembuhan Luka Pasca Ekstraksi Gigi Marmut. Dentika Dental Journal, 17(1):339.

[10] Atangwho I, Ebong P, Eteng M, Eyong E, \& Obi, A. 2007. Effect of Vernonia Amygdalina Del. leaf on kidney function of diabetic rats. International Pharmacology, 3(2):143-148.

[11] Linder M. 2006. Biokimia Nutrisi dan Metabolisme, Jakarta: UI-Press.

[12] Ashok PK, \& Kumud U. 2012. Tannins are Astringent. Journal Pharmacognosy Phytochemistry, 1(3):45-50.

[13] Georgewill O, \& Georgewill U. 2010. Evaluation of the Anti-inflammatory Activity of Extract of Vernonia amygdalina Leaves. Asian Pasific Journal Of Topical Medicine, 3(2):150-151.

[14] Larjava H. 2012. Oral Wound Healing: Cell Biology and Clinical Management, UK:Wiley-Blackwell.

[15] Miloro M. 2004. Peterson's Principle of Oral and Maxillofacial Surgery, 2nd Ed, London: BC Decker Inc.

[16] Ernawaty, Binatarti T, \& Handayani M. 2014. Efek Penyembuhan Luka Sediaan Gel Ekstrak Etanol Daun Afrika (Vernonia amygdalina Del.) pada mencit Jantan. Jurnal Ilmiah Pharmacist, 9(2):184-187.

[17] Mazza G. 2007. Saponins; Properties, Applications and Processing. Critical Review in Food Science and Nutrition, 47(3):231-258.

[18] Handayany GN, Mukhriani, \& Halim RM. 2015. Uji Efek Penyembuhan Luka Sayat Ekstrak Etanol Daun Kecombrang (Etlingera Elatior) dalam Bentuk Sediaan Gel Terhadap Kelinci. Jurnal Farmasi FIK Universitas Islam Alauddin Makasar, 3(2):55-58. 
Effect of African Leaves Extract (Vernonia amygdalina Del.) on Wound Healing Velocity After Tooth Extraction in Rattus norvegicus

[19] Eriadi A, Arifin H, Rizal Z, \& Barmitoni. 2015. Pengaruh Ekstrak Etanol Daun Binahong (Anredera cordifolia (Tenore) Steen) terhadap Penyembuhan Luka Sayat pada Tikus Putih Jantan. Jurnal Farmasi Higea, 7(2):162-173.
[20] Sentat T, \& Permatasari R. 2015. Uji Aktivitas Ekstrak Etanol Daun Alpukat (Persea americana Mill.) terhadap Penyembuhan Luka Bakar pada Punggung Mencit Putih Jantan. Jurnal Ilmiah Manuntung, 1(2):100-106. 